\title{
Gazing at South African higher education transformation through the potential role of the Wesleyan quadrilateral: A theological approach
}

\begin{tabular}{|c|c|}
\hline $\begin{array}{l}\text { Authors: } \\
\text { Mlamuli N. HI } \\
\text { Thabile A. Zon }\end{array}$ & $\begin{array}{l}\text { atshwayo }{ }^{1} \text { (D) } \\
\text { di }^{2} \text { (D) }\end{array}$ \\
\hline $\begin{array}{l}\text { Affiliations: } \\
{ }^{1} \text { Curriculum ar } \\
\text { Studies, Schoc } \\
\text { University of } \\
\text { Pinetown, Sou }\end{array}$ & $\begin{array}{l}\text { d Education } \\
\text { waZulu-Natal, } \\
\text { th Africa }\end{array}$ \\
\hline $\begin{array}{l}{ }^{2} \text { Geography D } \\
\text { of Education, } \\
\text { KwaZulu-Nata } \\
\text { South Africa }\end{array}$ & $\begin{array}{l}\text { scipline, School } \\
\text { University of } \\
\text {, Pinetown, }\end{array}$ \\
\hline $\begin{array}{l}\text { Correspondin } \\
\text { Mlamuli Hlats } \\
\text { hlatshwayom }\end{array}$ & $\begin{array}{l}\text { g author: } \\
\text { hwayo, } \\
\text { @ukzn.ac.za }\end{array}$ \\
\hline $\begin{array}{l}\text { Dates: } \\
\text { Received: } 12 \mathrm{~A} \\
\text { Accepted: } 26 \\
\text { Published: } 14\end{array}$ & $\begin{array}{l}\text { Uug. } 2019 \\
\text { Vov. } 2019 \\
\text { Oct. } 2020\end{array}$ \\
\hline $\begin{array}{l}\text { How to cite th } \\
\text { Hlatshwayo, } \\
\text { T.A., 2020, 'Ga } \\
\text { African higher } \\
\text { transformatior } \\
\text { potential role } \\
\text { Wesleyan qua } \\
\text { theological ap } \\
\text { Teologiese Stu } \\
\text { Theological St } \\
\text { a5782. https:/ } \\
\text { 10.4102/hts.v }\end{array}$ & $\begin{array}{l}\text { is article: } \\
\text { 1.N. \& Zondi, } \\
\text { zing at South } \\
\text { education } \\
\text { through the } \\
\text { of the } \\
\text { drilateral: A } \\
\text { proach', HTS } \\
\text { dies/ } \\
\text { udies } 76(1) \text {, } \\
\text { /doi.org/ } \\
76 \text { i1.5782 }\end{array}$ \\
\hline $\begin{array}{l}\text { Copyright: } \\
\text { (C) } 2020 \text {. The A } \\
\text { Licensee: AOS } \\
\text { work is license } \\
\text { the Creative C } \\
\text { Attribution Lic }\end{array}$ & $\begin{array}{l}\text { uthors. } \\
\text { IS. This } \\
\text { d under } \\
\text { ommons } \\
\text { ense. }\end{array}$ \\
\hline Read online: & \\
\hline 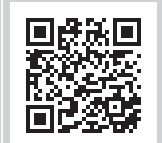 & $\begin{array}{l}\text { Scan this QR } \\
\text { code with your } \\
\text { smart phone or } \\
\text { mobile device } \\
\text { to read online. }\end{array}$ \\
\hline
\end{tabular}

The 2015-2016 South African higher education student movements evoked critical conversations regarding the extent to which institutions of higher learning have transformed into democratic and inclusive spaces. One of the key gaps in this field is the paucity of research that explores the potential role of theology in steering the direction of transformation in South African higher education system. Through a Wesleyan approach, the paper argues that the four quadrilaterals of the Wesleyn approach, scripture, tradition, reason and experience will be used as a theological tool to weight beliefs in the levels of dogma and doctrine, opinion and so as not to confuse critical reflection with negativity and judgmentalism in critically reflecting on the South African higher education struggles for transformation and decolonization. In our attempt to contribute meaningfully to the broader debates, started by scholars such as Nadar and Reddy (2015) and more recently, Phiri and Nadar (2018), who locate their work in theology to think through gender, curriculum and African feminism differently, counter-hegemonically. In this paper, we aim to contribute to this emerging body of work by arguing that theology has a critical role to play in helping us to imagine what a transformed, inclusive and socially just higher education could look like.

Keywords: South African higher education; Wesleyan quadrilateral; theology; transformation; decolonisation; social justice; student movements.

\section{Introduction}

South African higher education is currently facing a crisis (see, e.g., Habib 2019; Heleta 2016; Mbembe 2015). Recent calls for South African higher education triggered by the 2015-2016 student movements have exposed the extent to which transformation and decolonisation in institutions of higher learning have seemingly being delayed or are proceeding at a slow pace. These calls have often looked at the curriculum as deeply political and as an institution (Heleta 2016; Jansen 2009); the nature, direction and conditions of possibilities of student protests (Badat 2016b); the role of language as a socio-linguistic marker of exclusion and marginality in higher education (Mwaniki, Van Reenen \& Makalela 2018); the use of ubuntu [humanity] as an ethical tool for confronting coloniality through research, methodology and political agendas (Kumalo 2017; Naude 2017; Seehawer 2018); and experiences of black students, particularly those studying in historically white higher education institutions (Vincent \& Hlatshwayo 2018) and others. Recent calls for transformation have now begun to foreground socio-spirituality and scholars such as Buttelli and Le Bruyns (2018), Sithole (2015) and Wallace (2015) have attempted and called for a critical reflection on the role of religion and the enduring patterns of coloniality which are not critically reflected upon. In this article, we call for a 'theological shift' from the narrow 'white colonial' discourses to now look at the potential role that theological reflections can play to enable us to think for higher education transformation and decolonisation differently. The Wesleyan quadrilateral believes that the core foundation of understanding Christian faith is revealed through scripture, enlightened by tradition, witnessed in personal experience and witnessed by reason. Therefore, it can serve as a theological framework in helping us reflect on the possibilities of shifting South African higher education towards transformative discourses on matters related to issues on social justice.

This article begins with mapping the South African higher education terrain, providing a brief history of the sector, showing in the process how fragmented and institutionally differentiated higher education is in the South African context. Then it moves to introduce theological lenses of the article, that is, the Wesleyan quadrilateral as offering a useful framework in making sense of and contributing to the South African higher education transformation discourses. The central 
argument offers a critical discussion of how the Wesleyan quadrilateral's notions of scripture, tradition, reason and experience are all useful in the re-conceptualisation of higher education transformation through foregrounding the above key principles as enabling us to imagine a much more socially just and inclusive conception of higher education. The article now turns to map the South African higher education context.

\section{Mapping the context: Fragmentation, inequality and transformation}

We cannot discuss contemporary challenges that South African higher education is grappling with unless we first begin by historicising the system and show to what extent current challenges can be related with and located in the history of the sector.

South African higher education is profoundly shaped and structurally influenced by the apartheid regime (Badat 2010; Jansen 2004; Kraak 2004). The regime's attempt at racial segregation and intellectual difference meant that the institutions of higher learning were seen as socio-economic and linguistic epicentres of social engineering, with the hope that graduates would serve the needs of the apartheid state, while black students were relegated and tribalised to the Bantustan. Naidoo (2004) suggests that under the apartheid regime, there were essentially three kinds of universities: those in the domain tier, those in the intermediary tier and those in the subordinate tier. The dominant tier included universities that were established during the British colonial period and whose primary function was the spread of imperial colonial heritage and academic values in the colonies. It was against these universities that the apartheid period saw laws introduced in 1959, prohibiting them from admitting black students (Naidoo 2004). These universities were well-resourced, research-intensive universities and continue to dominate contemporary global rankings as well as research productivity in post-apartheid South Africa. It was predominately in this tier that the 2015-2016 student movement erupted in defiance against what was perceived to be the colonial, institutional heritage and traditions, the slow pace of transformation, an alienating curriculum, an institutional culture(s) that rejected them and other factors (Chaudhuri 2016; Murris 2016; Pillay 2016).

The intermediary tier included universities where Afrikaans was the main language and whose purpose was to serve as a counter-hegemonic influence against what was perceived to be the dominance of the English-speaking universities.

The primary function of these universities was to act as the socio-economic and linguistic reserve for the need of the Afrikaner state, and help produce the elites who would go on to contribute in the functioning and sustainability of the apartheid state through Afrikaner nationalism. The third and final tier included subordinated universities that were set up for the different black South Africans, and whose primary function, at least according to Badat (2016a), was to reclassify black people according to 'tribal' identities, and therefore the institutions of higher learning (i.e. the 'Bush colleges') were meant to enable black graduates to contribute to the emergence and sustainability of the 'independent' Bantustans. A significant amount of student movements emerged historically in this tier, joining in solidarity with students from the first tier to mobilise around issues of academic freedom, challenging the apartheid system as well as allying with the broader mass democratic movement (Badat 2016a; Clark \& Worger 2016; Heleta 2016). It should also be noted that since the beginning of the early 1990s, protest action had already been taking place in universities in the third tier, that is, historically black universities; however, because of media attention, geographic location, continuing marginality that universities on this tier still continue to face and other factors, their demands or protest have not been able to attract media attention. This results in scholars such as Badat (2016b) and Heleta (2016) cautioning us to not think of the 2015-2016 student movement as a new phenomenon in South African higher education, but rather a historical condition that never really ended for those in the third, subordinated tier.

In the early 1990s, the then incoming democratic government was confronted with the challenges of trying to transform higher education from the apartheid logic into democratic institutions that promote democratic thought, social justice and tolerance (Badat 2010, 2016b, 2017a). Although the very logic of higher education and its very 'DNA' had to change, priority was given to democratising access to the public university and ensuring that the historically Othered would belong. Overlooked in these early debates was the critical role that was needed to be played by the universities, the state and other organisations in tackling western epistemologies and knowledge systems that have been historically embedded in the life of the public university. This was seen in how access to the university was largely understood in the formal sense and access to the curriculum and knowledge was secondary to the broader debates (see Dhunpath \& Vithal 2012).

Although policy documents and reports such as the South African government's Education White Paper 3: A Programme for the Transformation of Higher Education (hereafter referred to as the Education White Paper 3) (1997) and the Report of the Ministerial Committee on Transformation and Social Cohesion and the Elimination of Discrimination in Public Higher Education Institutions (hereafter referred to as the Soudien Report) (2008) have mapped the urgency for transforming higher education, the snail pace of the transformation resulted in the 2015-2016 student movements re-centring transformation issues and calling for an urgent, decolonial transformation. While we acknowledge that different scholars have different conceptual understandings of what higher education transformation looks like, both philosophically and empirically (see Alasow 2015; 
Booysen 2016; Makgoba 1998), what seems to have broad consensus is that the current status quo is untenable and some form of urgent intervention is required. More recently, Valela (2015) and Naicker (2016) have called for the collapse of the distinction between the public university and society, and has referred to the student movement protests as the 'post-Marikana moment', one that shows the dialectical relationship between the inequality and marginality perpetrated by the South African state and the violence of the public university against black students:

This wave of campaigns waged by students across the country is also happening at a time in South Africa's history where we are dealing with more than just the post-Apartheid moment. We are in the post-Marikana moment. After 1994, it seemed highly unlikely (if possible) that a group of human beings would be shot and killed by state police considering the nation's history of police brutality under an unjust Apartheid regime. However, we are dealing with the reality that the colonial structure is not dismantled; therefore it should not come as a surprise that protest would be met with such violence. (Valela 2015)

Commenting on the relationship between state violence and the violence of the public university, Naicker (2016) speaks about the liberal media discourses that labelled the mineworkers as 'violent', 'irrational' and 'dangerous, and therefore befitting of state-sanctioned violence, like students at universities during the 2015-2016 protest actions':

\begin{abstract}
Marikana, as a type of politics, is not just about state violence against popular dissent. It is also about the ways in which the liberal media has aligned itself with the state to present poor black people organising themselves outside of authorised institutions as 'mobs' and 'thugs' who are 'irrational' and 'violent' and under the control of external agitators of various kinds. In recent weeks, exactly the same language has, for the first time in post-Apartheid South Africa, also been used to describe students at former English-speaking white universities like UCT and Rhodes. This development has shown that the liberal consensus is not only unable to engage the politics of poor black people on a reasonable basis. It is equally unable to respond to black students challenging liberal authority on a reasonable basis. This makes it clear that the limits to the forms of democracy acceptable to liberalism, and to the forms of political presence acceptable to liberalism, are about race as well as class. (Naicker 2016)
\end{abstract}

We now turn to outline the Wesleyan quadrilateral as a theological approach that could help us rethink South African higher education and begin to offer some solutions to the current controversies in institutions of higher learning;

\section{Introducing the Wesleyan quadrilateral}

There are many theoretical approaches that can be used to enable transformation in South African higher education. One of these approaches that we have used to frame this article is the Wesleyan quadrilateral.

The term 'quadrilateral' was coined by a Methodist scholar, Albert Outer, in the late 20th century, who was drawing from the work of the leader of the Methodist movement, John Wesley (Campbell 1991; Jones 1995). Wesley never used the term 'quadrilateral'; rather, it is used as a model to understand how he lived the Christian faith. The core understanding of the Christian faith according to Wesley can be achieved through four norms: scripture, illuminated by tradition, confirmed by reason and grounded in personal experience (Cosby 2001). Scripture is primacy as the first norm providing religious authority because, according to Wesley's doctrine, it reflects God's word, providing direction on how to live a Christian life (Crawford 2017). For the Wesleyan thought, scripture is central to all aspects of the Christian life and constitutes the sine qua non (central core) of Christian constitutive subjectivity.

Scripture is contained in the Old and New Testaments of the Bible, which preserve the revelation of God and his ways, building the foundation of the Christian faith (Hey \& Roux 2012). Therefore, in order to live a Christian life one has to first refer to the Bible to seek counsel as scripture provides an understanding on how Christians navigated relative issues in the past; furthermore, it provides Christian ethics that present-day Christians should live by. Wesley argued that the understanding of scripture alone was not enough for living a Christian life; this had to be supplemented by the other three norms (Crawford 2017) which form part of his quadrilateral. Tradition is the second norm of Wesley's quadrilateral; it refers to understanding Christian antiquity as a characteristic of Christian tradition, which serves as a reference for present-day believers because they refer back to the past to determine how Christians went about doing theology back then and apply those traditions in the present day (Jones 1995). Thus, this tradition can be seen as the teachings and the practices of the church such as Baptisms. Reason is the third norm of Wesley's quadrilateral.

Reason means rational analysis, which is a God-given gift that Christians use to interpret scripture. Reason comes from spiritual revelations as well as experience. Wesley argued that God has given everyone the ability to reason in order for them to be able to understand him and his ways (Hey \& Roux 2012). His ways are presented by scripture, tradition and experience; thus, Christians are expected to use reason to interpret scripture as it enables them to navigate life as they seek the face of God. However, Wesley recognised the limits of reason, stating that although reason plays a significant role in a Christian life it is coupled with experience (Cosby 2001). Human knowledge is grounded in experience; thus, reason and experience are intertwined.

Experience refers to both a religious and general experience of the world. According to Hey and Roux (2013), experience in Wesley's understanding refers to reflecting on the past and present journey with God, where a Christian has an encounter with the Holy Spirit. This encounter with God would serve as a personal assurance that indeed God is alive and through this experience Christians are able to share their testimonies 
and act as disciples to people who have not encountered or have recently encountered Christ, showing them that God is love and thus they spread the love that they draw from the source and infuse it with their own experience.

Reflecting on their encounter with God and what has been useful in their journey, they would share experiences of having their prayers answered as well as how God has come through for them in difficult times. Once more, experience alone cannot help a person in leading a successful Christian life. It has to be used in conjunction with the other norms mentioned above. The Wesleyan quadrilateral offers a useful theological and intersectional framework to think through the South African higher education calls for transformation and decolonisation. We draw on the four key concepts to help us intersectionally understand the current crisis grappling South African higher education.

\section{South African higher education through the Wesleyan quadrilateral}

Tradition, reason and experience are all dialectically at the heart of the South African higher education crisis.

Whose experience, what informs those experiences and which experiences are enabled and legitimated and which are silenced and marginalised were all highlighted during the 2015-2016 student protests (Badat 2017b; Booysen 2016; Khunou et al. 2019). Black students together with black academic staff have levelled sustained criticism at historically white universities in how they continue to be pushed to the margins of higher education (Alasow 2015; Khunou et al. 2019; Naicker 2016). Present in this dialectical existential crisis is the assumption that to be black is to be a disadvantage and that in order for one to survive and navigate the space, one has to conform to the dominant institutional culture. Describing this condition in one South African university as 'Afrikanerdom', the \#OpenStellenboschCollective describes the challenges of being black in a university that was historically built to harbour and reinforce a white supremacist Afrikaner national identity and apartheid ideology:

Every day students and staff who do not understand Afrikaans are excluded from learning and participating at Stellenbosch University. As black students we are frequently asked, 'Why do you come here if you can't speak Afrikaans?' This question highlights the pervasive and problematic sense of ownership that some have over this University. Stellenbosch - like all universities - is a public institution. This is not an Afrikaans university. It is a South African university which offers instruction in Afrikaans and (to a lesser extent) English. We have personally experienced countless instances of this institutional racism, including being forced to ask our Afrikaans-speaking peers to interpret what 'Huiskomitee' members are saying in residence meetings. (Open Stellenbosch Collective 2015)

In the above quotation, we see the use of language, hegemonic institutional cultures and institutional history as a political tool to silence and marginalise those who have undergone a different ontological experience. Hlengwa (2015) provides a careful critique regarding how universities in South Africa in general and historically white universities in particular have begun to employ what she refers to as 'safe bets' in ensuring that they 'grow your own timber' (see Tabensky \& Matthews 2015). In other words, the 'grow your own timber' becomes a discursive function that seeks to frustrate and deny the urgency of transformation through employing academics and students who fit 'neatly' and 'cleanly' with the dominant intuitional culture, and who will not interfere and frustrate the demands for transformation. In an insightful study, Booi, Vincent and Liccardo (2017) report on the employment of 'safe bets' in South African higher education as a cultural reproduction phenomena, where universities are preoccupied with employing the 'right kind of black' whose experiences align with the normative cultural practices of the university and have normalised the practices of the dominant groups:

Our findings suggest that senior white academics possess the means of cultural reproduction within the university structure because of their power to approve the 'right type' of black lecturers into academia who share the characteristics, values and normalised practices of the dominant group. The familiarity with white-middle-class culture is seen as a dispositional feature necessary to reproduce the institutional image and the university's existing 'way of doing things' or the only way of maintaining academic 'excellence'. Social capital, in the field where this study took place, takes the form of white-middle class habitus, where those who went to private schools and former Model C schools are seen as safe options to safeguard the institutional culture (own emphasis). (Booi et al. 2017)

According to Booi et al. (2017), safe bets are used in higher education to serve three functions. Firstly, they are there to give a semblance that higher education institutions in general and historically white universities in particular are at least taking demographic transformations seriously. Secondly, they are there to protect and reinforce dominant normative cultural practices and traditions so that the university status, power and privilege remain uninterrupted and not challenged. Lastly, it appears that the use of safe bets as a phenomenon in historically white universities is to ensure that real and material transformation is frustrated. Commenting on this existential two-ness, in how one is a safe bet and yet is simultaneously an ontological outsider, Ngcobozi (2015) writes about the \#RhodesSoWhite campaign organised at Rhodes University to shed light on the implicit and often hidden racism prevalent on campus:

The social media campaign attempted to show how racism exists not only on a macro level. Micro-aggression, or what I call 'palatable forms of racism', are [sic] as rancid as those who have the blood of our foremothers and fathers on their hands. The campaign was to bring to the fore the intersections of micro- and macro-aggression faced by black students on an institutional level, but also in their interactions with other students on campus. We must dispel the myth that palatable racism is not an assault or visceral crushing of black humanity. Although not surprising, a majority of those who felt offended by the campaign have adopted a politics of erasure and silencing, which, if not 
derailing the legitimate experiences and lived realities faced by black students at Rhodes University, have also been used as a tool to balance the debate. ... The very methodology of racism and the upholding of white supremacy works [sic] to distract the black political project of constituting and claiming black subjectivity. (Ngcobozi 2015)

In the above quotation, Ngcobozi (2015) and earlier Hlengwa (2015) (cited in Tabensky \& Matthews 2015) and Booi et al. (2017) argue about the two-ness of being a 'safe bet' in a university that allows and enables a student to progress, while ontologically being black and still marginalised. This discourse emanates from the claim that the student protest was led by those referred to as the 'coconuts' (see Chikane 2018), that is, middle class black students who come from privileged backgrounds and who attended private schooling. The operating logic of this discourse is that precisely because these black middle class students attended private schooling and have had, to some extent, privileged backgrounds, they ought to have had access to Bourdieu (2011)'s different forms of capital social that would enable them to have access to and take advantage of the higher education space and all the capitals it affords them. Chikane (2018) reflects on this existential phenomenon:

\begin{abstract}
My simple understanding of it, within the context of the alliance that coconuts and 1652s have with each other, is that a white society privileges certain forms of living above others. This form of thinking doesn't take on a racial profile, but it has a racial bias ... Those who became adept at this skill became the disciples of \#RhodesMustFall, which was tasked with the goal of spreading its word to all who would listen. Its purpose was to create a world that would love black people as they would love themselves. But if black people don't know how to love themselves, how do they expect others to love them? It was this conundrum, or rather this paradox, that gave rise to \#RMF. The movement came from an urgent need to make sense of a society built on contradiction.
\end{abstract}

The Wesleyan quadrilateral allows us to see the interconnected relationship between experience, tradition and reason. This is seen in how black students have offered an epistemic critique at what is often seen as a curriculum that seeks to favour 'dead white men' (Pett 2015) at the expense of traditional knowledge systems and intellectual traditions (see NdlovuGatsheni 2013, 2018a, 2018b).

Put differently, the institutional culture, university traditions and practices together with an alienating curriculum all constitute spatial and hermeneutical injustice for black students and black academics who have to navigate the challenges of higher education. This is best captured by Jansen (2018) and Mbembe (2015) who speak about transformation not in the traditional university or curricula sense, but transformation as a reformation of the self, as an ontological, existential process:

Right from the start of my career as a psychologist, I struggled with a sense of alienation, with feelings of resistance to the very idea of 'being a psychologist'. After qualifying as a psychologist I self-identified as a researcher in health program development for many years. I finally surrendered and ventured into a brief spell of private practice but I apparently never carried myself like a therapist. 'You do not behave like other psychologists' was the casual observation of the receptionist at the private practice where I rented room space ... Transformed assumptions of the self may translate into small steps forward in the project to decolonize psychology. At the heart of many local cultural and religious traditions is a social view of the self. The cross-cultural therapeutic encounter has a greater chance of success with enhanced sensitivity to the values of persons socialized in collectivist traditions (McCormick 1996). Even when people from collective traditions refer to their individual selves, it may still be with reference to their group selves. [author's own italics]

For Jansen, and to some extent for Mbembe (2015), transformation should firstly be understood in the ontological, phenomenological sense before it can manifest itself in the external realm. This is reinforced by Jansen (2018)'s argument that the discipline of psychology needs to focus on the self in relation to the field in knowing the enablements, constraints, challenges and opportunities faced by black academics in psychology and how to negotiate them. This ontological focus is premised on the understanding that although individuals act and behave within structures, understanding the self-first is important in whatever decolonial project or solutions we can think about. Mbembe (2015) refers to this as the 'pedagogies of presence' in calling us to cultivate a sense of citizenship and democratic thought rooted in strong mental dispositions, self-affirmation and epistemic diversity.

One of the most troubling phenomena to emerge from the South African higher education transformation discourses has been an emergence of essentialist and nativist discourses that seek to portray Africans in general and African-lived experiences as static, singular and un-touched by history and modernity (Makgoba 1996; Msila \& Gumbo 2016; Ndlovu-Gatsheni 2018b). This discourse, often influenced by the Africanisation school of thought, seeks to appeal to the African subject as singular, static and monolithic (see also Samuel 2017). This is seen in the largely particularistic arguments that suggest that 'beliefs and practices differ from society to society, that there is nothing universally valid, and that there are no universal truths' (see Etieyibo 2016:406-407). For this particularist school of thought, there is no such thing as universal knowledge, just different sets of beliefs and intellectual thoughts that inform and guide different societies and are subjective and useful to that particular area, society or community. Although this school of thought appears to foreground the Wesleyan quadrilateral's principles of experience, tradition and reason, it is nonetheless troubling in its rejection of cumulative knowledge-building and the global intersectionality of thought and experiences. Put differently, early African intellectual formulations and philosophies need to be thought of and exist in a global ecosystem of thought. It cannot be essentialised, separated and thought of as outside of global modernity. This was recently seen in Mangcu's (2013) intellectual biography on the work and life of Africana existentialist philosopher Steve 
Biko, in which he insists on relating Biko and his thought to the early Xhosa intellectual thinkers and chiefs. This level of de-intellectualising serves two purposes. Firstly, it seeks to re-present Biko as a local, Xhosa, intellectual, and secondly and perhaps more troubling for us, in that it relegates and dislocates Biko from the other Othered Global South philosophical thinkers such as Du Bois, Aimé Césaire, Fanon, Sartre, Senghor and others who all have contributed to his intellectual development (see More 2008). We now turn to explore the role of scripture in guiding and informing higher education transformation and decolonial practices.

\section{Re-turning to scripture}

This article strongly argues that theology in general and scripture in particular must play an active role in helping us rethink the clarion calls for South African higher education transformation. Similar to arguments made by the Latin American School of Liberation Theology, we argue that scripture and theological reflections cannot only be thought of in the abstract, theoretical sense. The living Gospel has a revolutionary and social justice ethic in touching the everyday lives and experiences of students. Gutierrez et al.'s (1988) argument that we need to pursue an emancipatory theology, one that offers 'critical reflection on praxis in light of the word of God', relates to our suggesting in calling for a bottom-up interpretation of the word, in ways that foster emancipatory pedagogy, critical citizenship and democratic thought. We draw our beliefs from the scripture on social justice:

Learn to do good; seek justice, correct oppression; bring justice to the fatherless, plead the widow's cause. (Is 1:17)

Open your mouth, judge righteously, defend the rights of the poor and needy. (Pr 31:9)

Thus says the Lord of hosts, Render true judgments, show kindness and mercy to one another, do not oppress the widow, the fatherless, the sojourner, or the poor, and let none of you devise evil against another in your heart. (Zch 7:9-10)

Thus says the Lord: Do justice and righteousness, and deliver from the hand of the oppressor him who has been robbed. And do no wrong or violence to the resident alien, the fatherless, and the widow, nor shed innocent blood in this place. (Jr 22:3)

The above passages indicate the scripture's emphasis on the importance of social justice, fighting for the oppressed and defending the rights of the poor. This means that the clarion call by the student movements, in calling into question, the colonial nature of higher education curricula; space and spatial justice in higher education, and how alienating the university has been for them required what we refer to as 'democratic empathy', that is, a critical understanding and commitment to action in responding to these challenges. Thus, scripture guides us that:

Therefore encourage one another and build one another up, just as you are doing. (1 Th 5:11)

And let us consider one another to provoke unto love and to good works: Not forsaking the assembling of ourselves together, as the manner of some is; but exhorting one another: and so much the more, as ye see the day approaching. (Heb 10:24-25)

Share each other's burdens, and in this way obey the law of Christ. If you think you are too important to help someone, you are only fooling yourself. You are not that important. (Gl 6:2-3)

One of the often-assumed and un-theorised aspects of the student protests has been the role that space and spatial justice continue to play in alienating those who occupy different ontologies (see Khunou et al. 2019; Puwar 2004; Valela 2015). How one experiences and lives through space is directly related to the consumption and critical engagement with reason (in curricula) and traditions of the institution. Collins's (1986) illuminating term, the 'outsider-within' status in calling into question how individuals may find themselves as outsiders when confronted with those who have access to and possess unequal power relations, is central to our argument. Collins (1999:86) refers to this condition as 'situational identities that are attached to specific histories of social injustice.' We see this in South African higher education in which the intersectionality between space and oppression plays a significant role in alienating both black students and back academics who continue to feel isolated and pushed out through the often unseen institutional cultural practices, departmental meetings, coffee sessions and other events that serve as implicit and hidden social and cultural reproduction platforms that decide who can be an insider in the department or university, and who does not belong. Commenting on this dialectical 'outsider-within' status, Khunou et al. (2019) narrate their challenges of being academics who are seen as 'quota candidates', not taken seriously as researchers and the existential crisis of seeming like, and at times, being treated like an imposter, like one does not belong to what Spivak (2012) refers to as the 'teaching machine' of higher education. Commenting on the challenges of navigating space in a historically white university and its spatial exclusion, Jagarnath (2015) reflects on the challenges of navigating what was a historical colonial fort and the implication this has for black subjectivities in Grahamstown:

Moving to Grahamstown to work at Rhodes University was a profound shock to my sense of myself and my place in the world. Grahamstown started out as a fort on the colonial frontier. It remains an evidently colonial town, one that wears its settler history with pride. The colonial mentality that pervades the town has a clear presence within the University itself. In various ways the university, and a few streets around the campus, still remain very much a bastion of white power, looking up at the hills where the dispossessed black population live. Today the white section of town is guarded by private security companies rather than a colonial militia. But in the heart of the white part of town, in the university, whiteness is still taken as normal context for academic life and as a mark of excellence.

In the above quotation, Jagarnath (2015) reflects on the challenges of navigating a space and institutional culture that seeks to exclude and marginalise black subjects. In this article, we look through the lens of scripture to think through the need for us to act in ways that fosters social justice and 
democratic understanding. This is seen in how biblical passages in Deuteronomy, Luke and Ephesians offer closer reading in how we can practise belonging, acceptance and fellowship with one another:

There will always be poor people in the land. Therefore I command you to be open handed toward your fellow Israelites who are poor and needy in your land. (Dt15:11)

Sell your possessions and give to the poor. Provide purses for yourselves that will not wear out, a treasure in heaven that will never fail, where no thief comes near and no moth destroys. Verse 34, for where your treasure is, there your heart be also. (Lk 12:33-34)

Anyone who has been stealing must steal no longer, but must work, doing something useful with their own hands, that they may have something to share with those in need. (Eph 4:28)

\section{Conclusion and recommendations}

We argue that the theological lens offers rich analytical insights into thinking seriously about the social justice nature of contested South African higher education struggles for transformation. We thus make the following recommendation for future research:

- The theological tools offered by the Wesleyan quadrilateral align well with the Latin American liberation theology and its progressive Gospel. Future research could possibly explore this theological relationship to a deeper extent and help us understand the complex and intricate nature of progressive thought, transformation and social justice struggles.

- The South African higher education literature that is largely influenced by the 2015-2016 student protests has often focused on the colonial and imperial nature of interpreting the world and has adopted a simplistic, bifurcated understanding of the differences between western modernity and African cultural understandings (see, e.g., Sithole 2015). Deeper theoretical and theological work, building on the work of Dube (2019), Nader and Van Klinken (2018) and others, shows that we still need to be dialectical showing the epistemic and theological possibilities offered by religion in general and scripture in particular to be used as a tool for social justice (Dube 2019; Nadar \& Gerle 2016; Nadar \& Van Klinken 2018).

- New and emergent critique, led by Appiah and Bhabha (2018), has adopted cosmopolitanism lenses as an alternative discourse in looking at the struggles for transforming knowledge. Future research could begin to respond to such clarion calls on how the Wesleyan quadrilateral in general and the progressive use of scripture in particular could, and to what extent, be dialectically seen as a cosmopolitan ethic.

South African higher education is currently trapped in and negotiating the struggles for transformation and decolonisation. Largely influenced by the 2015-2016 student movements, these issues have often ranged from an alienating and exclusionary nature of universities in South Africa, archaic curriculum practices, institutional cultures and the various ways that space and spatial justice intersect with institutional cultures to marginalise and oppress those who occupy different ontological subjectivities. The approach that has been adopted as an intersectional lens draws on the conceptual and theological tools offered by the Wesleyan quadrilateral in thinking of South African higher education transformation by means of the dialectical and intersectional roles of scripture, tradition, reason and experience.

\section{Acknowledgements Competing interests}

The authors have declared that no competing interest exist.

\section{Authors' contributions}

All authors contributed equally to this work.

\section{Ethical consideration}

This article followed all ethical standards for a research without direct contact with human or animal subjects.

\section{Funding information}

This research received no specific grant from any funding agency in the public, commercial or not-for-profit sectors.

\section{Data availability statement}

Data sharing is not applicable to this article as no new data were created or analysed in the study.

\section{Disclaimer}

The views and opinions expressed in this article are those of the authors and do not necessarily reflect the official policy or position of any affiliated agency of the authors.

\section{References}

Alasow, J.G., 2015, 'What about Rhodes (University) must fall?', Daily Maverick, 23 March, 2015.

Appiah, K.A. \& Bhabha, H., 2018, 'Cosmopolitanism and convergence', New Literary History 49(2), 171-198. https://doi.org/10.1353/nlh.2018.0010

Badat, S., 2010, 'The challenges of transformation in higher education and training institutions in South Africa', Development Bank of Southern Africa 8, 4-56.

Badat, S., 2016a, Black student politics: Higher education and apartheid from SASO to SANSCO, 1968-1990, Routledge, Pretoria.

Badat, S., 2016b, 'Deciphering the meanings, and explaining the South African higher education student protests of 2015-16', Pax Academics 1, 71-106, viewed 30 September 2018, from https://www.sahistory.org.za/archive/decipheri.

Badat, S., 2017a, 'The idea of higher education as an instrument for social mobility and societal transformation', in Soudien, C. (ed.), Nelson Mandela, pp. 125-136, Springer, Cape Town. https://doi.org/10.1007/978-94-6300-908-9_10

Badat, S., 2017b, 'Trepidation, longing, and belonging: Liberating the curriculum at universities in South Africa, Public Lecture Series on Curriculum Transformation Matters', The Decolonial Turn at the University of Pretoria 1-26. https://doi org/10.13140/RG.2.2.31255.57765

Booi, M., Vincent, L. \& Liccardo, S., 2017, 'Counting on demographic equity to transform institutional cultures at historically white South African universities?' Higher Education Research and Development 36(3), 498-510. https://doi.org/ 10.1080/07294360.2017.1289155

Booysen, S., 2016, Fees must fall, Wits University Press, Johannesburg.

Bourdieu, P., 2011, 'The forms of capital (1986)', in I. Szeman \& T. Kaposy (eds.), Cultural theory: An anthology, pp. 81-93, Wiley-Blackwell, Chichester. 
Buttelli, F.G.K. \& Le Bruyns, C., 2018, 'Decolonising theology from\# Feesmustfall and\# Foratemer', Religion and Theology 25(1-2), 46-71. https://doi.org/10.1163/ 15743012-02501010

Campbell, T.A., 1991, 'The 'Wesleyan Quadrilateral': The Story Of A Modern Methodist Myth', Methodist History 29(2), 87-91.

Chaudhuri, A., 2016, 'The real meaning of Rhodes must fall', The Guardian, 16 March 2016 , p. 16

Chikane, R., 2018, 'Breaking a rainbow, building a nation: The politics behind \#MustFall movements', Daily Maverick.

Clark, N.L. \& Worger, W.H., 2016, South Africa: The rise and fall of apartheid, Routledge.

Collins, P.H., 1986, 'Learning from the outsider within: The sociological significance of black feminist thought', Social Problems 33(6), s14-s32. https://doi.org/ $10.2307 / 800672$

Collins, P.H., 1999, 'Reflections on the outsider within', Journal of Career Developmen 1(1), 85-88. https://doi.org/10.1177/089484539902600107

Cosby, M.R., 2001, 'Using the Wesleyan Quadrilateral to Teach Biblical Studies in Christian Liberal Arts Colleges', Teaching Theology and Religion 4(2), 71-80.

Crawford, N., 2017, 'Improvising with the Quadrilateral: An Augustinian Approach to Recovering the Use of the Wesleyan Quadrilateral in the Theology of Preaching', The Asbury Journal 72(1), 8-19.

Dhunpath, R. \& Vithal, R. (eds.), 2012, 'Alternative access to university: Past, present and future', in Alternative access to higher education: Underprepared students or underprepared institutions, pp. 2-20, Pearson, London.

Dube, B., 2019, 'Is gabola a decolonial church or another trajectory of freedom of religion in post-colonial South Africa? Rethinking ethical issues in religious praxis', Religions 10(3), 167. https://doi.org/10.3390/rel10030167

Etieyibo, E., 2016, 'Why ought the philosophy curriculum in universities in Africa be Africanised?' South African Journal of Philosophy 35(4), 404-417. https://doi.org/ 10.1080/02580136.2016.1242208

Gutierrez, G., Inda, C., Eagleson, J. \& Inda, C., 1988, A theology of liberation: History politics, and salvation, Orbis Books, Maryknoll, NY.

Habib, A., 2019, Rebels and Rage: Reflecting on \#FeesMustFall, Jonathan Ball, Johannesburg.

Heleta, S., 2016, 'Decolonisation of higher education: Dismantling epistemic violence and Eurocentrism in South Africa', Transformation in Higher Education 1(1), 1-8. https://doi.org/10.4102/the.v1i1.9

Hey, S. \& Roux, J., 2012, 'Wesley and Beyond: Integrating the Wesleyan Quadrilatera and "Praxis Cycle" to Support Tertiary Student Theological Engagement,' JATE 9(2) 192-209.

Jagarnath, V., 2015, 'Working while black at Rhodes', Daily Maverick.

Jansen, J. (ed.), 2004, 'Changes and continuities in South Africa's higher education system, 1994 to 2004', in Changing class: Education and social change in postapartheid South Africa, SAICA, pp. 293-314.

Jansen, J., 2009, 'The curriculum as an institution in higher education', in E. Blitzer (ed.), Higher education in South Africa: A scholarly look behind the scenes, vol. 1, pp. 123-154, Sun Media, Stellenbosch.

Jansen, S., 2018, 'Decolonizing the self, transforming psychology', Mail \& Guardian.

Jones, S.J., 1995, John Wesley's conception and use of scripture, Kingswood Books, Nashville.

Khunou, G., Phaswana, E.D., Khoza-Shangase, K. \& Canham, H., 2019, Black academic voices: The South African experience, HSRC Press, Cape Town.

Kraak, A., 2004, 'Discursive tensions in South African higher education, 1990 to 2002', Journal of Studies in International Education 8(3), 244-281. https://doi. org/10.1177/1028315304265337

Kumalo, S.H., 2017, 'Problematising development in sustainability: Epistemic justice through an African ethic', Southern African Journal of Environmental Education 33(1), 14-24. http://doi.org/10.4314/sajee.v33i1.2

Makgoba, M.W. (ed.), 1998, 'South African universities in transformation: An opportunity to Africanise education', Black perspective(s) on tertiary institutional transformation, pp. 42-62.

Makgoba, W., 1996, 'South African universities in transformation: Africanise or perish', Politeia 15(2), 114-118.

Mangcu, X., 2013, Biko: A life, IB Tauris, London.

Mbembe, A., 2015, 'Decolonizing knowledge and the question of the archive', Aula magistral proferida.
More, M.P., 2008, 'Biko: Africana existentialist philosopher', in A. Mngxitama A. Alexander \& N.C. Gibson (eds.), Biko Lives! Contemporary Black History, Palgrave Macmillan, New York.

Msila, V. \& Gumbo, M.T., 2016, Africanising the curriculum: Indigenous perspectives and theories, African Sun Media, Stellenbosch.

Murris, K., 2016, '\# Rhodes Must Fall: A posthumanist orientation to decolonising higher education institutions', South African Journal of Higher Education 30(3), 274-294. https://doi.org/10.20853/30-3-653

Mwaniki, M., Van Reenen, D. \& Makalela, L., 2018, 'Advanced language politics in South African higher education post\# RhodesMustFall', Southern African Linguistics and Applied Language Studies 36(1), 25-36. https://doi.org/10.2989/ 16073614.2018.1452876

Nadar, S. \& Gerle, E., 2016, 'Mediating the 'sacredness' of religion, culture and law in contexts of sexual violence', Agenda 30(3), 104-114. https://doi.org/10.1080/101 30950.2017.1284302

Nadar, S. \& Reddy, S., 2015, 'God's Justice Is Social Justice Exploring African Feminist Theologies in a Masters Programme at Two South African Higher Education Institutions', The Ecumenical Review 67(4), 591-606.

Nadar, S. \& Van Klinken, A., 2018, 'Queering the curriculum: Pedagogical explorations of gender and sexuality in religion and theological studies', Journal of Feminist Studies in Religion 34(1), 101-109. https://doi.org/10.2979/jfemistudreli.34.1.16

Naicker, C., 2016, 'From Marikana to\# feesmustfall: The praxis of popular politics in SouthAfrica', Urbanisation1(1),53-61.https://doi.org/10.1177/2455747116640434

Naidoo, R., 2004, 'Fields and institutional strategy: Bourdieu on the relationship between higher education, inequality and society', British Journal of Sociology of Education 25(4), 457-471. https://doi.org/10.1080/0142569042000236952

Naude, P., 2017, 'Decolonising knowledge: Can Ubuntu ethics save us from coloniality?' Journal of Business Ethics 159(Suppl. 3), 1-15. https://doi. org/10.1007/s10551-017-3763-4

Ndlovu-Gatsheni, S., 2013, 'Decolonising the university in Africa', The Thinker 51, 46-51.

Ndlovu-Gatsheni, S., 2018a, 'Decolonising research methodology must include undoing its dirty history', The Conversation, 26 September 2017.

Ndlovu-Gatsheni, S., 2018b, Epistemic freedom in Africa: Deprovincialization and decolonization, Routledge, New York.

Ngcobozi, L., 2015, '\#RhodesSoWhite: An insight', The Con Magazine, 27 March 2015.

Open Stellenbosch Collective, 2015, 'Open Stellenbosch-Tackling language and exclusion at Stellenbosch University', Daily Maverick, 28 April 2015.

Pett, S., 2015, 'It's time to take the curriculum back from dead white men', The Conversation, 08 May 2015.

Phiri, L. \& Nadar, S., 2018, 'To move or not to move! Queering borders and faith in the context of diverse sexualities in Southern Africa', in D.L. Machado, B.S. Turner \& T.E. Wyller (eds.), Borderland Religion: Ambiguous practices of difference, hope and beyond, Routledge, London.

Pillay, S.R., 2016, Silence is violence: (Critical) psychology in an era of Rhodes must fall and fees must fall, Sage, London.

Puwar, N., 2004, Space invaders: Race, gender and bodies out of place, Berg.

Samuel, M.A., 2017, 'Africanising the curriculum: Indigenous perspectives and theories', in V. Msila \& M.T. Gumbo (eds.), Educational Research for Social Change, pp. 87-92.

Seehawer, M.K., 2018, 'Decolonising research in a sub-Saharan African context: Exploring Ubuntu as a foundation for research methodology, ethics and agenda' International Journal of Social Research Methodology 21(4), 1-14. https://doi.org/ $10.1080 / 13645579.2018 .1432404$

Sithole, N., 2015, 'Decolonising the word: Themba Masinga and his religious poetry in Ibandla LamaNazaretha', Religion 45(2), 191-208. https://doi.org/10.1080/00487 21X.2014.992109

Spivak, G.C., 2012, Outside in the teaching machine, Routledge, New York.

Tabensky, P.A. \& Matthews, S., 2015, Being at home: Race, institutional culture and transformation at South African higher education institutions, UKZN Press, Pietermaritzburg.

Valela, N., 2015, 'The Rhodes to perdition: Why Rhodes was never ready for the BSM', Daily Maverick, 26 March, 2015.

Vincent, L. \& Hlatshwayo, M., 2018, 'Ties that bind: The ambiguous role played by social capital in black working class first-generation South African students negotiation of university life', South African Journal of Higher Education 32(3), 118-138. https://doi.org/10.20853/32-3-2538

Wallace, D., 2015, 'Rethinking religion, magic and witchcraft in South Africa: From colonial coherence to postcolonial conundrum', Journal for the Study of Religion 28(1), 23-51. 